\title{
洗浄における機械力 \\ Mechanical Force in Textile Washing
}

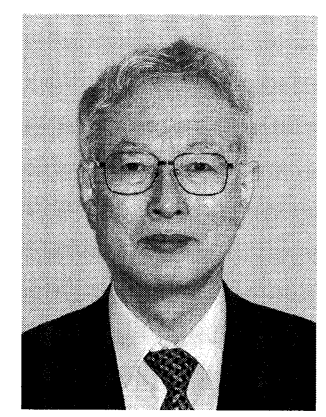

\author{
長谷川富市 \\ 新潟大学工学部機械システム工学科 \\ T950-2181 \\ 新潟市西区五十嵐 2 の町 8050 \\ Tomiichi HASEGAWA \\ Mechanical and Production Engineering \\ Faculty of Engineering \\ Niigata University \\ Ikarashi 2-no-cho, 8050 \\ Nishi-ku, Niigata-shi 950-2181, JAPAN
}

論文要旨：洗濯洗浄における機械力を, 布の変形と摩擦に対する寄与および洗液の流れに対する寄与に分 け，それぞれについて従来の研究結果を紹介し，その位置づけと意味するところを述べた。また，機械力を 積極的に利用して洗浄に必要なエネルギーや洗䠼を減らす方法についても言及した。さらに, 洗液の流体力 学的特性や動的表面張力についても記した。とくに, 布に与えたエネルギーはある值以下では洗浄に有効に 働くけれども，その值以上では洗浄に有効に働かないこと，および，洗剤水溶液は污れの付着力を弱めると いう化学的作用の他に，糸あるいは緘維間流れの流動抵抗を隇少させ水に比べて大きな流量を実現させるこ とにより污れを落とす効果のあることが述べられている。

\begin{abstract}
Researches on mechanical force in textile washing have been reviewed. Mechanical force exerts its effect through various factors; bending, friction and elongation of textile, and the flow on the textile surface or the flow between yarns or fibers. The present report mentioned positioning and meaning of researches so far carried out on these factors. Also, the author introduced washing methods developed for the purpose to reduce energy and detergent by utilizing the mechanical force positively. Furthermore, he stated both the fluid property and the dynamic surface tension of liquids concerned with washing. In particular, the following two points were stressed: (1)Energy provided to textile is effective below its certain value, but it is of no use beyond the value and the excess energy is only wasted. (2)Aqueous solutions of detergent provide an effect to reduce the drag of flow through yarns or fibers and to increase the flow rate, resulting in easier removal of soil than in water, as well as the effect to lessen the chemical potential between soil and substrate.
\end{abstract}

Key words: Mechanical force, Textile washing, Detergent, Surfactant solution, Dynamic surface tension

\section{1 はじめに}

一般に, 洗濯洗浄の污れ除去に関わる種々の要因は化 学作用と物理・機械作用に大別され (注 1), 後者は機 械力と呼ばれる。しかし，実際の洗浄における機械力は 多種多様であり，かつそれらの多くは単独で作用せず相 互に複雑に関係している。したがって, 機械力の各要因 を単独で取り出し, その効果を議論することが妥当であ るという保証はない。しかしながら，解析の手始めとし て単純なモデルから始めて各要因の効果を評価し, 次第

連絡者：長谷川富市

E-mail : hasegawa@eng.niigata-u.ac.jp
に実際の洗濯洗浄の解明に近づくことは有効な手段と考 えられる。日本における洗濯洗浄の多くは洗液中におけ る布の運動により行われるが, 機械力を実験的に調べる 場合, Fig. 1 のように, 機械力の寄与を布の変形（曲げ, せん断, 伸び・圧縮）と摩擦（布同士，布と固体壁）お よび洗液の流れ（布表面上の流れ, 織糸や繊維間を通過 する流れ）に分けて行う。柏らは全洗浄力に対する機械 力の割合をある仮定のもとで求め, 通常の洗濯機の洗浄 条件では，機械作用の寄与は約 $50 \%$ で残り $50 \%$ が洗剂 の界面化学作用の寄与であったと報告している ${ }^{1)}$ 。しか

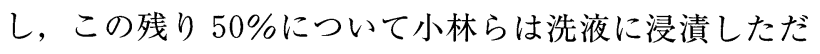
けで洗浄される界面化学作用は約 $3 \%$ で, 残り $47 \%$ は洗 


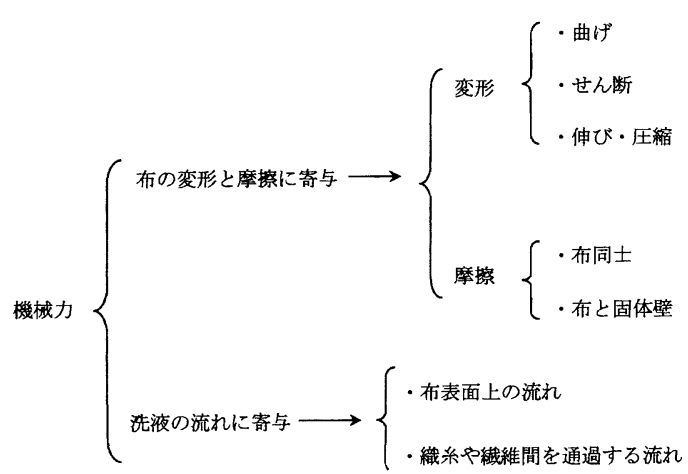

Fig. 1 機械力（実験上の分類）

剤の界面化学作用と機械力の相乗作用であったとし，洗 浄における機械力の寄与がより大きいことを強調してい る る $^{2}$ (注 2)。さらに，小林らは各種機械力の効果をモデ ル装置を用いた実験により調べている ${ }^{3)}$ 。以下に，今日 まで得られた機械力に関する研究成果を概観する。

\section{2 布の変形と摩擦に寄与する機械力}

\section{$2 \cdot 1$ 布の変形}

洗濯時の衣類はさまざまな変形を受けつつ污れを落と している。その変形が実際の洗濯洗浄にどの程度の役割 を果たしているかを調べる実験が多田によって行われ た $^{4-6)}$ 。その結果，洗浄時に自由変形および振り変形（振 りによる強制変形）させた場合の洗浄率は，無変形のそ れよりも2〜3倍も高く, 変形の重要性が示された。こ れと同時に布の変形を定量的に把握するために変形を単 純な様式に分類しこれについて解析を行う必要性のある ことが指摘された。変形様式は, Fig. 1 に示すように, せん断，曲げ，伸び（圧縮）に分けられる。

\section{$2 \cdot 1 \cdot 1$ せん断変形の効果}

多田は布地にせん断変形を加えて洗浄効果を調べる害 験を行った ${ }^{7-9)}$ 。実験装置を Fig. 2 に示す。同一洗浴中

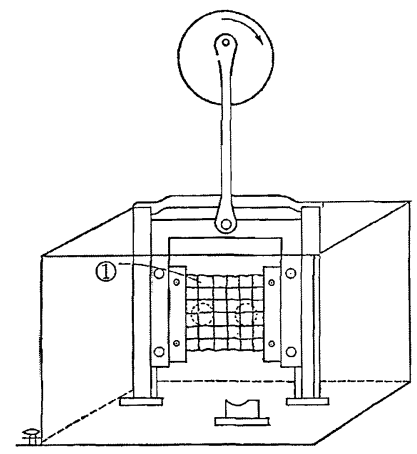

a) 洗浄槽と無変形洗浄装置 (1)無変形で振動洗浄される 污染布（無変形布と略称）

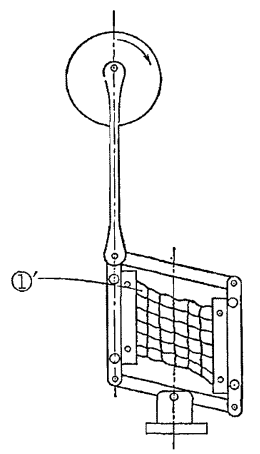

b）せ九断変形洗浄装置 (最高位置)

(1) せん断変形して洗浄される 活染布（变形布と略称）
Fig. 2 せん断変形洗浄装置

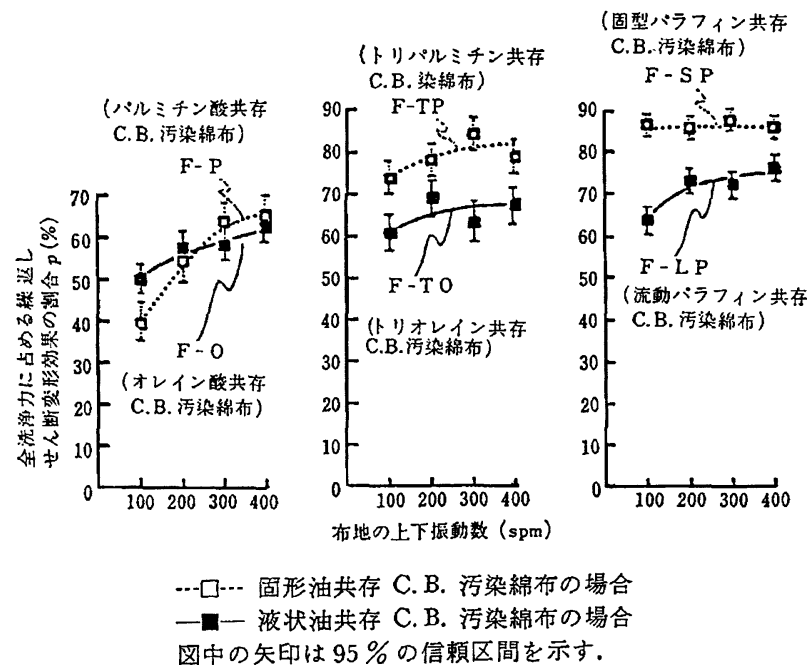

Fig. 3 繰返しせん断変形洗浄の効果が全洗浄力に 占める割合 $(p)$ の，共存油性污れ別比較

に，2枚の污染布を同時にセットし，一方にはせん断変 形を繰り返し加え, 他方は変形無しで上下運動を繰り返 えさせる。そして, 両者の洗浄効率の差からせん断変形 による洗浄効果を算出した。実験結果の一部を Fig. 3 に 示す。せん断変形による洗浄効果が全洗浄力に占める割 合 $p$ の高さが見て取れる（ $p$ の定義については文献 8 を 参照)。他の実験結果を含めて以下の結論が得られた。

1. 布地の上下振動数が 100 から $400 \mathrm{spm}$ に増大するに つれて，せん断変形布の洗浄効率曲線は著しく上昇 したが，無変形布の洗浄効率の上昇は微弱であっ た。このことから，洗浄にはせん断変形が大きな効 果をもつことが明らかとなった。

2. せん断変形の効果が全洗浄に占める割合は，布地の せん断速度に対応しており，30９0\%の範囲に分布 した。洗浄時間の大小には対応しなかった。

3. せん断変形の効果は, 液状の油性污れを共存する人 工污染布よりも，固形油共存の人工污染布の方が大 きかった。

\section{$2 \cdot 1 \cdot 2$ 曲げ変形および摩擦（布と固体壁間）の効果}

布地に特定の曲げ変形（特定の曲率）を与えて洗浄害 験を行うために, Fig. 4 に示す原理による実験が行われ た（実験装置図および説明は省略する $)^{10,11) 。 す な わ ち ， ~}$ 布地に一定の曲げ変形を与えるために直径 $2 r$ の円柱の 中央部を間隔 $l_{0}$ だけ細く削りとり，円柱に沿うように布 を取り付ける。布に上下の往復運動を与えると円柱に 沿って運動する部分 (C 部, 幅 $l_{1}$ ) は, 円柱に接触しな い状態（A 部，曲率 $\kappa=0 ）$ から円柱に接した摩擦あり の状態 (C 部, 曲率 $\kappa=1 / r$ ) への曲げ変形を行う。し たがって中央の円柱に触れない部分（B 部，幅 $l_{0}$ ) も摩 擦無しの状態で前記とほぼ同じ曲げを受けることにな 


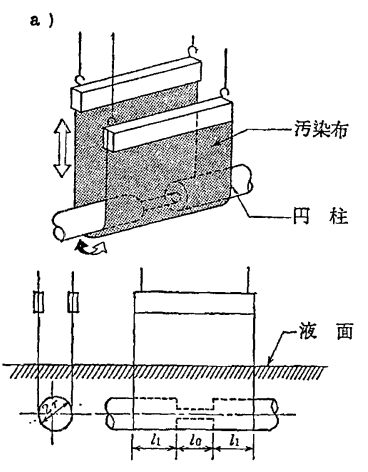

b)

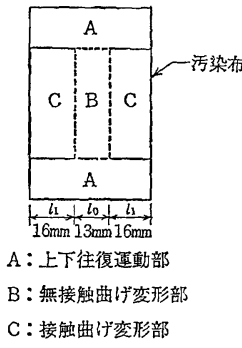

a) 实験装置原理図

b) 污染布の洗浄部分

Fig. 4 曲げ・摩擦・液流, 各単独の効果 を調べるための洗浄装置原理図

る。この実験により，得られた結果を Fig. 5 に示す。 Fig. 5-1 は, 試験布各部について, 縦軸に洗浄効率 $\Phi_{1}$, 横軸に変形の往復回数 (cycles) をとったものである ${ }^{10)}$ 。 この図から，各部の $\Phi_{1}$ の值は大きい順に $\mathrm{C}, \mathrm{B}, \mathrm{A}$, 比較 資料（浸漬洗浄布）であり，往復回数が増すと上昇する 傾向にあるが，A，B，C 部は 1,000 回付近まで，浸漬洗浄 布では 200 回相当時間付近まで上昇して以後ほぼ一定值 となっている。また，この図の往復回数の多いところを

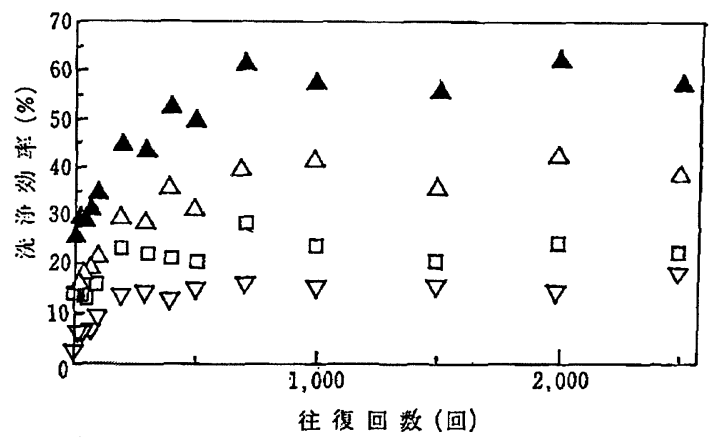

円柱径 $6 \mathrm{~mm}$

$\square \mathrm{A}, \triangle \mathrm{B}, \Delta \mathrm{C}, \nabla$ 漫漬洗浄布

Fig. 5-1 往復回数に対する A, B, C 各部の洗浄効率 $\left(\Phi_{1}\right)$ 。 ここにおける $\Phi_{1}$ は，正確には反射洗浄率（\%) と いうべきものであり，次式で定義される。 $\Phi_{1}=100 \times \frac{R_{w}-R_{s}}{R_{0}-R_{s}}$ 。ここで, $R_{w}$ : 洗浄後の各部の 反射率, $R_{s}$ : 洗浄前の污染布の反射率, $R_{0}$ : 污染 前の原白布の反射率，である ${ }^{10)}$ 。

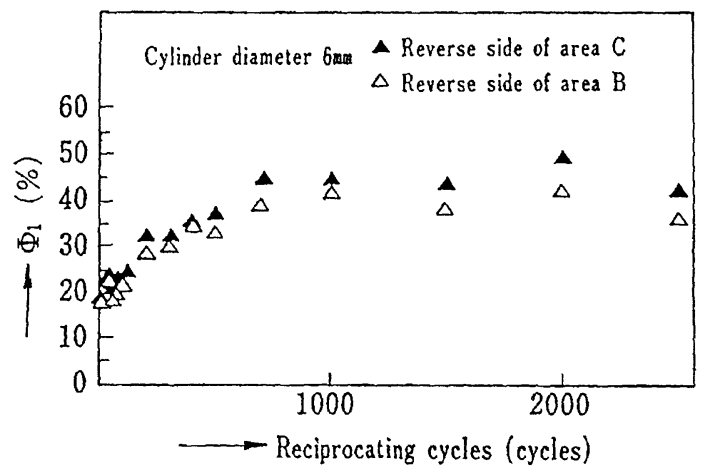

Fig. 5-2 B, C 部の裏面における洗浄効率（曲げの効果）

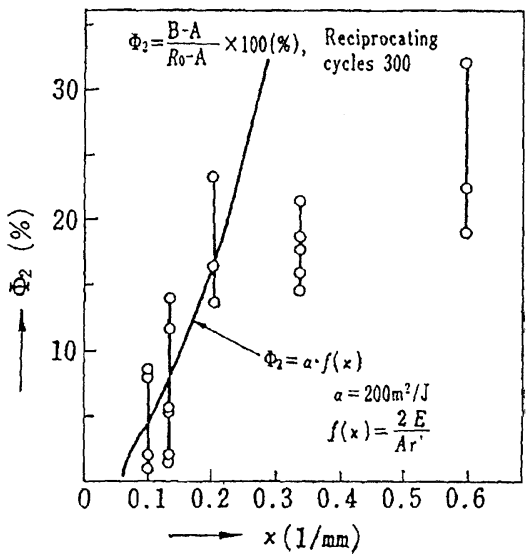

Reciprocating cycles $=300$;

$\Phi_{2}$ means bending effect.

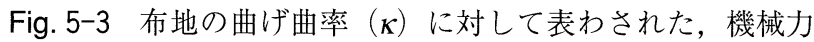
の最大達成值をもとに算定した曲げによる洗浄効 率 $\left(\boldsymbol{\Phi}_{2}\right)$ 。

$\Phi_{2}$ は曲げの効果を示すために導入した洗浄効率 （\%）で，次式で定義される ${ }^{10)}$

$\Phi_{2}=100 \times \frac{B-A}{R_{0}-A}$ 。ここに, $B-A$ は曲げによる効

果, $R_{0}-A$ は機械力によって達成される最大洗浄 効果を表わし， $A, B$ は，それぞれ, Fig. 4 に示す $A, B$ 各部の（布の表の）反射率である。図中の実線 $f(\kappa)=\frac{2 E}{A r}$ は布地に与えた単位面積当たりのエネル ギー $\left(\mathrm{J} / \mathrm{m}^{2}\right)$ であり，別の実験から求められたも のである ${ }^{10)} 。 こ こ に, ~ E$ は布地に与えたエネルギー, $A r$ は布地面積を示す。また, 図中の $\alpha$ は $\left(\mathrm{m}^{2} / \mathrm{J}\right)$ の次元をもつ実験定数である。

見ると，曲げ・摩擦・液流・浸漬の効果を含む $\mathrm{C}$ 部の $\Phi_{1}$ が約 $60 \%$ ，浸漬効果のみの $\Phi_{1}$ が約 $15 \%$ ある。 した がって，この場合の機械力（これは曲げ・摩擦・液流か ら成る）が，全洗浄効果に占める割合は $(60-15) / 60=$ 0.75 となる。この実験では曲げに使用した円柱直径が 6 $\mathrm{mm}$ であるが，同種の実験で直径 $10 \mathrm{~mm}$ の円柱を使用 した場合の上記数值は 0.82 となる ${ }^{10)}$ 。このことを考え合 わせると, 本実験の全洗浄に占める機械力の割合は約 8 割である。しかし，この実験はせん断変形の効果を含ま 


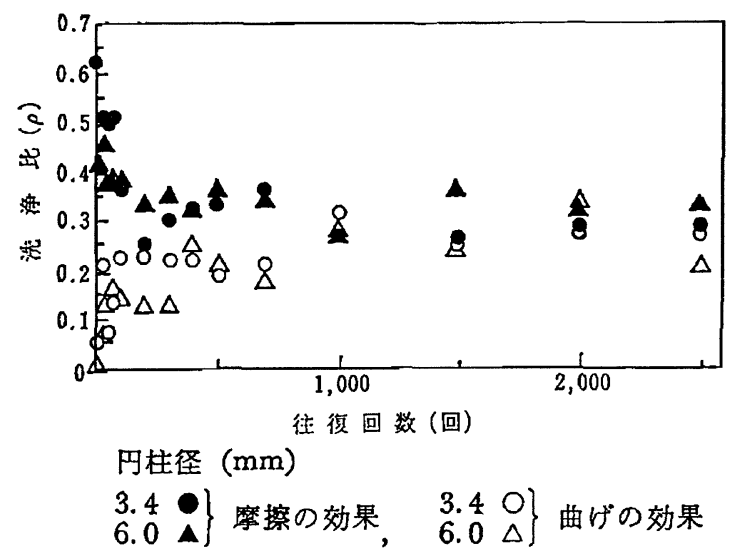

Fig. 5-4 曲げの効果と摩擦の効果が全洗浄効果に占める割 合 $(\rho)$ 。

$\rho$ (friction) および $\rho$ (bending) は各々全洗浄効果 に対する曲げおよび摩擦の効果の占める割合を示 し, 次式で定義される。

$\rho($ friction $)=100 \times \frac{C-B}{C-R_{\mathrm{s}}}$,

$\rho$ (bending $)=100 \times \frac{B-A}{C-R_{s}}$ 。ここに, $A, B, C$ は,

Fig. 4 に示す， $A, B, C$ 各部の（布の表の）反射率 である10)。

ないため，実際の洗浄では機械力がさらに大きな割合を 占めることが考えられる。このことは，小林ら ${ }^{2)}$ の結果 と同様に, 洗浄における機械力の寄与が極めて大きいこ とを示唆している。Fig. 5-2 は B, C 部の布地裏（すなわ ち円柱側の布地面と反対の布地面，布地は $\mathrm{C}$ 部の表で円 柱と接している）における $\Phi_{1}$ の值を示す。これによれ ば，布地裏は $\mathrm{B}, \mathrm{C}$ 部ともほとんど差がなく，かつ Fig. 5-1 と比較するとそれは B 部の表とほぼ同じ值であるこ とが分かる。このことは, 曲がりの効果が表・裏に関し てほほ同等であることを示している。Fig. 5-3 は曲げの 効果を表す洗浄効率 $\Phi_{2}$ を曲げの曲率 $\kappa$ に対して示して

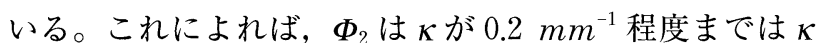
に対し単調に増加するが，それ以上曲率を大きくしても 洗浄効果は上がらないことが分かる。したがって，曲げ の効果にはある臨界の曲率がありその曲率を超えて布に 曲げを与えても洗浄効率はほとんど上昇しないことが分 かる。また，図中の曲線は別の実験から求めた布に与え たエネルギーを示す ${ }^{10)}$ が， $\Phi_{2}$ は， $\kappa$ が小さい範囲でエ ネルギーに対応して増加するけれども，上記の臨界曲率 $\left(\kappa=0.2 \mathrm{~mm}^{-1}\right)$ を超えるとエネルギー曲線から離れ，与 えたエネルギーは洗浄に有効に働かないことが分かる。 なお，平松らは種々の洗浄様式について，洗浄効率がエ ネルギーによって整理できることを示した ${ }^{12,13)}$ 。Fig. 5-4 は曲げおよび摩擦の効率が全洗浄効果に占める割合 $\rho$ を 往復回数に対して表している ${ }^{10)}$ 。これによれば往復回数 の少ないところで摩擦による洗浄比が高く，曲げによる
それは低いが, 回数 1,000 を超えると両者ともほほ同じ 值を示している。つまり，摩擦の効果は洗浄の初期のこ ろに顕著であり，曲げの効果は摩擦の効果より時間的に 遅れて表れるが，時間が経過すると（本実験では回数 1,000 以上)，両者ともほぼ同じ割合に落ち着くことが分 かる。したがって本実験の洗浄について，曲げの効果

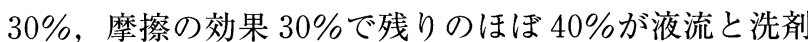
による効果ということができよう。

\section{$2 \cdot 1 \cdot 3$ 伸びと圧縮}

布に伸びや圧縮そのものを与えて洗浄効果を調べた実 験が小林らにより行われた ${ }^{3)}$ 。これによれば引張・圧縮 による洗浄効果は他の機械力と比較し，かなり小さいこ とが分かる。一般に，洗浄時において布の伸びや圧縮は 単独で生じることは少なく，多くはせん断変形に伴って 生じると考えられる（材料力学の教えるところによれ ば，材料はせん断の主方向に伸ばされその直角方向で圧 縮を受ける)。したがって，伸びや圧縮を単独で調べた 実験例は少なく，上記以外に見当たらないようである。

\section{$2 \cdot 2$ 摩擦}

Fig. 1 に示すように，摩擦には布同士，および，布と 固体壁の場合が考えられる。布と固体壁については前述 した ${ }^{10)}$ ので，ここでは省略する。一方，布同士の摩擦に ついては，それのみを取り出して洗浄効果をみた実験は 見当たらないようである。しかし，これと似た条件の実 験が，実用的観点から，ブラシ洗いに対する実験として 行われ，以下の結論が得られた ${ }^{14,15)}$ 。すなわち，先ず， モデル実験から，（i）ブラシへアが合成瀻維の場合は， 供試ブラシ間の洗浄効率の順位と, 累積摩擦洗浄仕事量 の順位，ヘアの太さの順位，ヘア束の曲げ剛さの順位が よく一致すること，(ii）ブラシへアが動物性・植物性の 天然繊維の場合は，上記の関係は必ずしも一致しないこ と，(iii）同一ブラシについて，垂直加重が増すと，へ アが挫屈しない条件下では，累積摩擦洗浄仕事量も洗浄 効率も増大すること，次に，人力による実験から，(iv） 8 種類のブラシの洗浄効率の大小の順位は，モデル穾験 による結果とほぼ一致すること，(v) 各ブラシへア間隙 に含まれうる洗剤液量の大小の順位は，各ブラシの洗浄 力の順位と一致しないこと，が明らかとなった。

\section{3 洗液の流れに寄与する機械力}

\section{$3 \cdot 1$ 布表面上の流れ}

基質上にある固形污れの剥落に関して Vissser は回転 二重円筒間の流れを用いたモデル害験を行った ${ }^{16,17)}$ 。 すなわち，内筒上に貼り付けられたセルロース膜上にポ リスチレン粒子を付着させ，高速で内筒を回転させると 粒子はせん断流による抗力と遠心力を受ける。剥落した 
粒子の数を数えることにより, 液の PH や Van der Waals 力の影響を調べた。また, 日景らは, 2 次元流路内の層 流せん断流れにおいて固体壁に付着した粒子の剥離状態 を一連の実験により観察した ${ }^{18-20)}$ 。用いた粒子は，ポリ スチレンラテックス粒子，ポリスチレン粒子，ガラス粒 子である。また, 供試基質はセルロース, ガラス, アセ テート, ポリエステルの 4 種類であった。この結果, 粒 子種類に関わらず, 剥離し難さの度合いは, セルロー スくガラス<アセテートくポリエステルの順であった。 さらに，粒子径の大きい粒子ほど剥離に大きな力が必要 であった。天木らは污れモデルを想定した微小円柱を壁 面に付着させ，水と界面活性剂（LAS, AE）水溶液の層 流せん断流を微小円柱に直角に当てることにより円柱の 抗力を算出した ${ }^{21)} 。 こ の$ 結果, LAS, $\mathrm{AE}$ 水溶液ともに 水よりも低い抗力值を与えることを示した。渡辺らは壁 面近傍の微小円柱を過ぎる粘弾性流体の流れによる抗力 と揚力を数值解析により求め, 以下のこと等を明らかに した ${ }^{22)}$ 。抗力係数 $C_{D}$ は弾性力と粘性力の比であるワイ センベルク数 $W_{i}$ に対して大きく変化しない。これに対 し, 揚力係数 $C_{L}$ は $W_{i}$ とともに線形的に減少する $\left(C_{L}\right.$ は $W_{i}$ が負值をとる場合は増加する)。 $C_{L}$ のこの変化は $C_{D}$ の変化と比較すると非常に大きい。以上の研究から, 洗液が粘弾性を有していればそれが洗浄性に大きく影響 することが予想される。

\section{$3 \cdot 2$ 織糸および織維間を通過する流れ}

長谷川らは，洗液流に垂直に置かれた人工污染布の洗 浄性を実験的理論的に解析し，布地貫流による洗浄効率 を表す式を提案した ${ }^{23)}$ 。また，天木らは，矩形流路内に 流れに直角に張られたメッシュスクリーンを通過する水 と界面活性剤水溶液の圧力損失を測定した ${ }^{24)} 。 こ の$ 結 果, 洗濯洗浄で用いられる数種類の界面活性剂について は，水よりも小さな圧力損失が見出された。このこと は，これらの界面活性剤水溶液は水と比較して織糸・繊 維間を容易に流れるという性質を有していることを示し ている。したがって, 洗剤の効果は, 化学的に污れの付 着力を弱めることに止まらず，織糸・繊維間に大きな流 速をもたらすことによって流体による機械力を増加さ せ，污れを落とし易くしているものと推測される。

以上実験的に機械力を解析する方法およびその結果に ついて述べた。次は, 機械力を積極的に利用する洗浄方 法について述べる。

\section{4 機械力を積極的に利用する洗浄方法}

\section{$4 \cdot 1$ 吒き洗い}

洗濯機が普及する以前から, 吒き洗いは人力による他 の洗濯技法に比べて洗浄力の高いことが知られていた。
これに着目して, 多田は吒き棒による吒き洗いの洗浄性 に関する実験的観察を行い，以下の点を明らかにし $た^{25,26)}$ 。（i）積層された被洗布の各層の洗浄効率は一様 でなく, 洗浄力の高い順位は最表層 》最下層の数層 > 中間層であった。（ii）渦巻き式標準洗濯機による洗浄効 率に比較して, 最表層の洗浄効率はそれより明らかに高 かった。その他の層ではそれより低くて実用の洗浄力は 得られなかった。（iii）したがって，衣類の污れた部分 を次々に表層に出して叨けば，効率の良い洗浄ができる ことが分かった。（iv）表層の洗浄力は，2 種の供試吒き 棒の重さの影響はあまり受けなかった。このことは，本 稿 $2 \cdot 1 \cdot 2$ で述べたように，ある限度を超えると布に与え たエネルギーは有効に働かなくなることに対応してい る。吒き洗いに関する研究は，モデル実験装置を用いて 現在も進行中である ${ }^{27-30)}$ 。

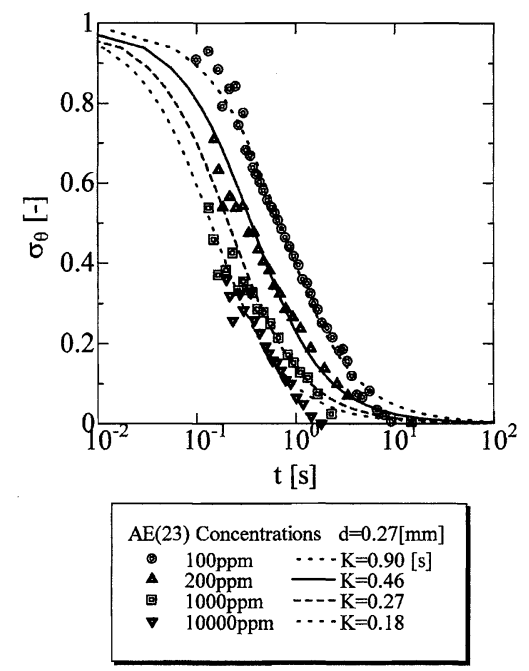

Fig. 6-1 規格化した無次元動的表面張力 $\left(\sigma_{\theta}\right)$ 対 生成時間 $(t)$ 。図中の実線，点線は式(1) を表す。

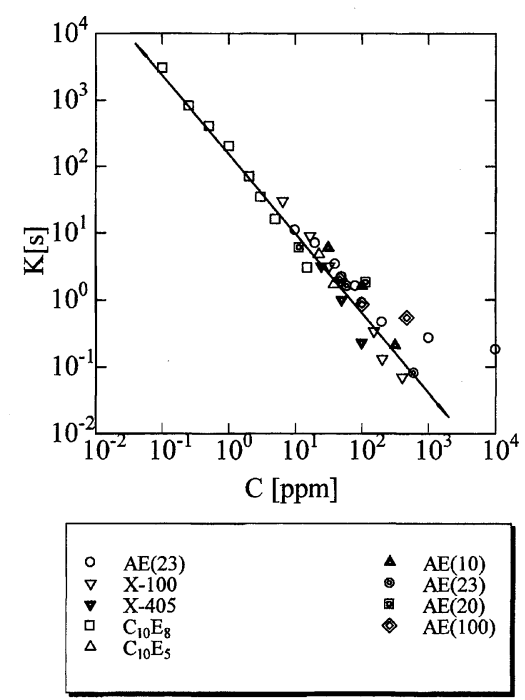

Fig. 6-2 実験定数 $(K)$ 対 濃度 $(C)$ 


\section{$4 \cdot 2$ 交番流による洗浄}

長谷川らは, 布の曲げ・摩擦, 布地の貫流などの機械 力を積極的に利用して洗浄力を高めようとする実験をモ デル機により行った ${ }^{31)}$ 。その結果，市販の洗濯機による 洗浄効率を大きく上回る洗浄効率を得ることができた。 さらに，唐澤らはこの交番流で用いる洗液に気泡を混入 させることにより，洗浄効率を落とすことなく使用洗剂 量を $50 \%$ 程度削減できることを示し，洗浄効率は洗液 の動的表面張力と密接に関係していることを明らかにし $た^{32)}$ 。

\section{5 動的表面張力}

前節で述べたように，機械力に気泡の効果を加えると 洗浄効率が大きく上がるが，この場合，洗液の通常の （静的）表面張力ではなく動的表面張力が重要となる。 これについて, 長谷川らは, 従来複雑な過程のために数 值計算から求めざるを得なかった動的表面張力につい て，界面活性剂分子の水面上での運動をモデル化するこ とによって次に示す簡便な式を導いた

$$
t=\frac{K}{2}\left(\frac{1}{\sigma_{\theta}}+\frac{1}{2} \log \left(\frac{2-\sigma_{\theta}}{\sigma_{\theta}}\right)-1\right)
$$

ここに， $t$ は界面生成後の経過時間（表面時間）， $\sigma_{\theta}$ は規格化された無次元動的表面張力， $K$ は実験定数で, 界面活性剤分子が水面で回転運動をするために要する時 間の目安を意味する。Fig. 6-1に AE (23) に対して得ら れた実験值と式(1) との比較を示すが， $K$ として同図下 に記す值を取ると，両者はよく一致することが分かる。 また，Fig. 6-2 は種々の界面活性剂水溶液に対する $K$ を 濃度 $C[p p m]$ に対して示すが，各種の界面活性剤に対し て両者は両対数グラフで一本の直線で表され，

$$
K=185 C^{-1.19}
$$

の関係にあることが分かった ${ }^{33)}$ 。

\section{6 おわりに}

以上述べてきたように，洗浄全体に占める機械力の寄 与は誠に大きなものがあり，機械力をさらに有効に利用 すれば洗剤使用量の大幅な削減が可能である。しかし， 大きな機械力を与えればそれに見合った洗浄率が得られ るかというとそうではなく，ある限界を超えると与えた 機械エネルギーは洗浄に有効に利用されずに無駄となっ てしまう。したがって，洗剤使用量削減という目的の他 にエネルギー的にも機械力を有効に利用した高効率の洗 浄方法が望まれる。このような新たな洗浄方法の開発 は，産官学の共同研究に最も適したテーマの一つであ り，多方面の方々がこれに参加されて開発を進め，機械 力を有効に利用した新たな洗濯機が一般に使われる日の
早からんことを期待するものである。

\section{謝 辞}

本総説執筆に当たり，筆者を洗濯洗浄の研究に導いて くださり，また，今回は貴重な資料を提供して戴いた多 田千代先生に深く感謝申し上げます。また，筆者に本総 説執筆の機会を与えてくださり, 加えて有益なコメント と多くの文献を賜りました，お茶の水女子大学教授駒城 素子先生に心からの謝意を表します。

注 1 : 本文中の「化学作用」および「物理・機械作 用」を，文献 1)，2，3)では，それぞれ「物理化学作用」 および「機械作用」としている。本総説では, 物理学が 力学を含む学問体系であることに鑑み, 機械作用と一緒 にして物理・機械作用とした。化学に物理化学という分 野があって，その関係で物理化学という用語を使うこと も理解できるが，ここでは上記の理由で，洗浄を化学作 用と物理・機械作用とに分類している。

注 2 ：文献 1)，2，3)では，水のみによる洗浄効果が機 械力による効果であるとし，洗剤を溶かした水溶液（以 下，これを洗液といい，洗浄に水のみを使う場合は単に 水ということにする）中で布に機械力が加わった場合の 効果を相乗効果と称している。本総説では, 洗浄に洗液 を用いることを前提として, 浸漬洗浄効果を機械力が零 の洗浄効果（すなわち, 化学的作用による洗浄効果） と し，何らかの機械力が加わった場合に得られる洗浄効果 から浸漬洗浄効果を差し引いた残りを機械力による効果 とする。

\section{文献}

1）柏 一郎, 平林 隆, 角田光雄, 大場洋一, 油化学, 20, 304-9 (1971).

2) 小林 晃, 森 国人, 岸本由信, 永井真一, 天野美俊, ナショナルテクニカルレポート, 18, 705-13(1972).

3）小林 晃，森 国人，中澤敏一，第 6 回洗浄に関する シンポジウム要旨集, 31-6 (1974).

4）吉永フミ, 多田千代, 西出伸子,「被服整理学」, 光生 館，昭和 63 年新版第 1 刷, p.110

5）多田千代：県立新潟女子短大研究紀要, No.10, 111-7 (1973). 吉永フミ，多田千代，西出伸子，「被服整理学」, 光生館，昭和 63 年新版第 1 刷, p.111

6）多田千代：家政学雑誌，昭和 59 年度学会賞受賞記念論 文, 35 (8), 519-528 (1984).

7) 多田千代 : 家政学雑誌, 30 (2), 178-82 (1979).

8）多田千代：家政学雑誌, 30 (3), 278-85 (1979).

9）多田千代：家政学雑誌, 30 (8), 691-6 (1979).

10）長谷川富市, 多田千代, 油化学, 32 (7), 397-402 (1983).

11）長谷川富市, SEN'I GAKKAISHI (繊維と工業), 61 (9), 232-4 (2005).

12）平松 俊，小谷昭子，緘維製品消費科学, 22 (5), 186-90 
(1981).

13）平松 俊，小谷昭子，繊維製品消費科学, 25 (2), 83-6 (1984).

14）多田千代，矢崎浄子，家政学雑誌, 34 (11), 705-12 (1983).

15）多田千代，矢崎浄子，家政学雑誌，34 (12), 788-797 (1983).

16) J. Visser, J. Colloid Interface Sci., 34 (1), 26-31 (1976).

17) J. Visser, J. Colloid Interface Sci., 55 (5), 664-76 (1976).

18）日景弥生，岩崎芳枝，矢部章彦，繊維製品消費科学，34 (3), 135-41 (1993).

19）日景弥生，岩崎芳枝，矢部章彦，繊維製品消費科学，34 (12), 660-7 (1993).

20）日景弥生，岩崎芳枝，矢部章彦，纎維製品消費科学，35 (1), 41-9 (1994).

21）天木桂子, 長谷川富市, 近野正昭, 日本レオロジー学 会誌, 21 (1), 41-5 (1993).

22）渡辺 博, 長谷川富市, 鳴海敬倫, 玉野 健, 日本機 械学会論文集 (B 編), 61-582, 393-8 (1995).

23）長谷川富市, 多田千代, 油化学, 34 (7), 545-50 (1985).
24) K. Amaki, T. Hasegawa \& T. Narumi, Nihon Reoroji Gakkaishi (J. Soc. Rheology, Japan), 36 (3), 125-31 (2008).

25）多田千代，家政学雑誌，30 (8), 683-90 (1979).

26）多田千代，家政学雑誌，33 (9), 474-81 (1982).

27）落合 綾, 駒城素子, 萱場龍一, 長谷川富市, 第 33 回 洗浄シンポジウム要旨集, 53-7 (2001).

28）落合 綾，駒城素子，萱場龍一，長谷川富市，第 15 回 瀻維連合研究発表会講演要旨集, 91 (2002).

29）元木加世, 駒城素子, 長谷川富市, 第 38 回洗浄シンポ ジウム要旨集, 39-42 (2006).

30）元木加世, 駒城素子, 長谷川富市, 繊維学会予講集, 241 (2007).

31）長谷川富市, 鳴海敬倫, 近野正昭, 多田千代, 油化学, 36 (6), 418-25 (1987).

32) M. Karasawa, T. Hasegawa, M. Komaki \& T. Narumi, $J$. of Oleo Sci., 55 (10), 521-27 (2006).

33) T. Hasegawa, M. Karasawa \& T. Narumi, J. Fluids Eng., 130, 081505 (2008). 